\title{
The Relationship of Mother's Work Status and Emotional Mental's Problem at Preschool Students of TK Annur III Maguwoharjo Sleman Year 2018
}

\author{
Ratih Handayeni ${ }^{1, *}$, Evi Nurhidayati ${ }^{2}$ \\ ${ }^{1,2}$ Faculty of Health Science, Universitas Aisyiyah Yogyakarta, West Ringroad 63 of Nogotirto Street Gamping \\ Sleman 55292, Yogyakarta, Indonesia \\ ${ }^{1}$ ratihhandayeni@yahoo.co.id* \\ * corresponding author
}

Submission date: 10 Juli 2018, Receipt date: 10 Oktober 2019, Publication date: 1 Juli 2020

\begin{abstract}
The problem of children's growth in preschool age can decrease the human resource quality in the following days when it cannot be detected in early phase. Mother's assistance of her children is very needed in the first 5 years of golden age. This is the phase where they play and learn with their mother. This study was done to compare between non worker mothers and worker mothers with the problems of emotional mental. The purpose of this study was to identify the relationship of mother's work status and emotional mental problem at preschool students at TK Annur III Maguwoharjo, Sleman Year 2018. This study was an analytic survey with CrossSectional Approach. The independent variable was the problem of emotional mental, and the dependent variable was the mother's work status. The population in this study involved all workers and non-worker mothers with 149 of students at TK Annur III Maguwoharjo, Sleman while the samples were 140 students. The questionnaire of this study used Emotional Mental Method as a prime data. The Design of sampling was non probability sampling as a simple consecutive sampling. Statistical analysis for data evaluation were carried out by using Chi Square $p=<0.005$. The analysis results showed the work status of mothers with emotional mental problems at preschool students at TK Annur III Maguwoharjo, Sleman (P-Value=0.000) with the odd ratio was 415.4; 95\% CI; 51.6 to 3339.8. There was significant relationship between mother's work status and problems of emotional mental at the preschool students of TK Annur III Maguwoharjo, Sleman.
\end{abstract}

Keywords: Mother's Work Status, Emotional Mental, Preschool Students

\section{INTRODUCTION}

The development of healthy as a part of human's efforts which are held to increase the children's health in the early phase of their life start in the womb until they are in the first of 5 years of their life. The purpose of it is to keep the children's life and increase the quality of it so they can get the optimal growth physically, mentally, emotional, social, and has the complex intelligence as its genetic potential ${ }^{3}$. 
The targets of Sustainable Development Goals (SDG's) in point 2 and point 3 in year of 2030 are to reduce the mortality of infant and child and to have the commitment with all the countries to decrease the neonatal mortality's number at least 12 per 1.000 of births, to reduce $1 / 3$ of premature death which are caused of non-contagious diseases, prevention and care, also to push the health and security of mental ${ }^{4}$.

The growth and development of children are influenced by the role of their parents. The age of preschool is a basic phase which has big impact to their next level of growth. It is a short period and this is known as a 'critical period' or 'golden age'. The problem that appears in the preschool age can make the quality of human resource in the future to become worse when it cannot be detected early

The genetic' factors, social of economy, and environments are the points in reaching the better growth and development. In Indonesia, there is no a valid data to show the percentage of children in interference of metal emotional. There are 4.2 millions of children with a special need in Indonesia, which include of physic interference, social mental, and emotional ${ }^{5}$. This number predicts the increase number of children mental disorder.

The prevalence of emotional and behavior disorder at preschool students is $34.10 \%{ }^{6}$. While according to Maramis (2013), 74.2\% respondents has emotional and behavior disorder. Furthermore, $50.08 \%$ is recommended to visit the children growth clinic and $14.5 \%$ gets the counseling therapy ${ }^{7}$.

The environment of nursing is very important for the first of 5 years in children's life (social learning and approaching model). This is predicted that it can influence the children's emotional and behavior disorder. Nowadays, many women go to work as a compensation to support family's income. According to data from Statistic Centre in 2003, from $100 \%$ of women, showed there are $82.68 \%$ of worker women and rest $17.31 \%$ are non-worker women. During they work, women are hard to give their time and to pay attention to their kids. This condition is so worried because it can impact the growth and development of their kids ${ }^{8}$

Mother is one of main factor in family that influences to the growth of kids and play a role in teaching their kids especially in period of child. Mother's roles are categorized into 3, as raw model, as stimulator, and as a teacher ${ }^{9}$. The researchers of children health development consistent to show that they need a stable relationship in their family, a responsive adult, care and productive, a safe neighborhoods so they can explore without any scare, good nutrition, and also health care ${ }^{10}$. According to Belsky et al (2001), a duty of mother influence directly the growth of her children towards her ways in making a close relationship ${ }^{11}$.

In the previous research said that children tend to spend their time without any supervision of their parents when they are working, whereas it can destroy their goals at schools and increase their participation in risk behavior ${ }^{12}$. As a worker woman, mother gets a better life in their work world, family's demand, concentration and attention will influence her, has a negative feeling ${ }^{13}$.

The assistance of mother to their children is very needed in the first of 5 years in their golden age. Children's period in learning and playing is the most thing to be fulfilled with their mother. This research was done to compare the worker women and non-worker women in emotional mental problem. This study purposes to know is there any relationship between mother's work status and emotional mental problem at preschool students of TK Annur III Maguwoharjo, Sleman Year 2018. 


\section{RESEARCH METHODS}

This study used the analytic study with cross sectional approach. The independent variable was the emotional mental problem, and the dependent variable was the mother's work status. The population of this study was all worker mothers and nonworkers mother with the preschool students of TK Annur III Maguwoharjo, Sleman, of 149 respondents and 140 respondents for its sample. The questionnaire of Emotional Mental Problem was used as a prime data in this study. The design of sampling used the non-probability sampling method with total population sampling.

The inclusion criteria of this study were parents who had preschool children age of 4-6 years old and they agreed to involve in the study, both parents and children are staying in the same house. The exclusion of this study were parents who has preschool children age 4-6 years old and they refused to be respondents, if in filling the questionnaire marked as uncomplimentary study. Exclusion criteria in the study of parents had preschool children aged 4-6 years who were not willing to become respondents, if the filling of the research equipment was considered incomplete. The sample in this study were 140 respondents. The research instrument used the Emotional Mental Problem Questionnaire (KMEE) as primary data. The sampling design uses nonprobability sampling method with the type of total population sampling.

Univariate analysis was carried out to explain or describe each research variable and bivariate analysis to determine the interaction of two variables by chisquare statistical test with $\mathrm{p}$-value $<0.05$. In addition, in this study to determine the risk by calculating Odd Ratio (OR).

\section{RESULTS AND DISCUSSION}

Table 1. Variable Frequency Distribution of Research

\begin{tabular}{lccc}
\hline \multicolumn{1}{c}{ Variable } & Category & n & \% \\
\hline \multirow{2}{*}{ Employee Status of Mother } & Rest & 68 & 48,6 \\
& Work & 72 & 51,4 \\
\hline \multirow{2}{*}{ Problem of Emotional Mentally } & Unsignificant with Emotional Mentally & 77 & 55 \\
& Significant with Emotional Mentally & 63 & 45 \\
\hline
\end{tabular}

Table 1 Univariate analysis shows that most working mothers were 72 people (51.4\%), and 68 people (48.6\%) mothers did not work. The number of working mothers was more than the number of mothers not working. Working mothers did not have full time for their children than working mothers. The distribution of mental emotional problems in preschool children had no more problems than disturbances, namely 77 $(55 \%)$.

Table 2. Results Relationship of maternal employment status with mental emotional problems in preschool children

The Healty of Emotional Mentally

\begin{tabular}{ccccccc} 
Kharacteristics & \multicolumn{2}{c}{$\begin{array}{c}\text { Unsignificant with } \\
\text { Emotional Mentally }\end{array}$} & $\begin{array}{c}\text { Significant with Emotional } \\
\text { Mentally }\end{array}$ & & \multirow{2}{*}{ Total } \\
\cline { 2 - 6 } & $\mathbf{N}$ & $\mathbf{\%}$ & $\mathbf{N}$ & $\mathbf{\%}$ & $\mathbf{N}$ & \% \\
\hline Rest & 67 & 87 & 1 & 1,6 & 68 & 48,6 \\
Work & 10 & 13 & 62 & 98,4 & 72 & 51,4 \\
Total & 77 & 100 & 63 & 100 & 140 & 100 \\
\hline
\end{tabular}


Table 2 Bivariate analysis shows that out of 77 total children who did not experience mental emotional problems, 67 (87.0\%) of them were cared for by mothers not working. Of the 63 children with mental emotional problems, 62 children $(98.4 \%)$ were cared by working mothers. Bivariate analysis using chi-square analysis to evaluate the variables of maternal work status had the potential to relate to mental emotional problems with a P-value $<0.05$. The analysis showed that the education status of mothers with mental emotional problems in preschool children in Annur III Maguwohrjo Kindergarten, Sleman (P-value 0.000) with Odd Ratio of 415.4; 95\% CI; 51.6 to 3339.8 . From the data above, it shows that the mother's work status increased the risk of mental emotional problems in preschool children by 415 times. The results above indicated that the hypothesis was accepted.

Growth and development in children is influenced by the role of parents. Growth and development during preschool is a basic stage that is very influential and becomes the basis for further development. This period is short so it is called the critical period or golden gold. No matter how small the growth and development occur in children in preschool age, if it is not detected and intervened as early as possible it will reduce the quality of human resources in the future.

In this study, the prevalence of mothers worked was more than mothers who did not work. The role of mothers is very significant in the family, especially in their children. As explained in the National Center for Women's Education (2005) study, Japanese men spend an average of more than 3 hours with children per day, compared to an average of 7.5 hours for mothers in Japan to spend time with children ${ }^{14}$.

Research in North America shows that conflict in employment, domestic work is very likely to have an impact on maternal depression ${ }^{15}$. This is supported by research based on data from families with low socioeconomic and child welfare, the study revealed that mothers with depression due to work can increase the likelihood of poor mental health in children in their first 5 years of age ${ }^{16}$.

Non-working mothers can provide care and full attention to the needs of children so as to prevent the occurrence of mental emotional problems. This is in line with research that says that mothers who spend time at home have children with fewer emotional problems. The index of behavior is lower, children also tend to be happier and not depressed ${ }^{17}$. Working mother has a dual role in addition to being a career woman as a housewife. One of the negative effects of working mothers is that they cannot give full attention to their children when the child is in an optimal stage of growth and development. Though mothers have an important role in child care. Therefore, proper care is needed so that children can grow and develop optimally.

\section{CONCLUSION}

This study explains the relationship between the employment status of mothers and mental emotional problems. Working mothers have a dual role in addition to being a career woman as a housewife. One of the negative effects of working mothers is that they cannot give full attention to their children when the child is in an optimal stage of growth and development. Though mothers have an important role in child care. 


\section{REFERENCES}

Badan Pusat Statistik (BPS). 2003. Survei Demografi dan Kesehatan Indonesia (SDKI) 2002-2003.

Belsky J. (2002). Emanuel Miller lecture: Development Risks (still) Associated with early child care, Journal of Child Psychology and Psychiatry,2001;42: 845-59

BKKBN. 2013. Anak Berkebutuhan Khusus Jadi Perhatian BKKBN. Retrieved. June 26, 2015, from http://www.bkkbn.go.id/ViewBerita.aspx?BeritaID-844.

Heinrich CJ. (2014). Parents' employment and children's wellbeing. The future of children Journal. 24(1):121-146

Kemenkes RI. 2007. Pedoman Pelaksanaan Stimulasi, Deteksi dan Intervensi Dini Tumbuh Kembang Anak di Tingkat Pelayanan Kesehatan Dasar. Jakarta

Maramis. (2013). Gangguan Mental Emosional pada Anak Usia 3-5 Tahun di Desa Pucang Bimo Kecamatan Bandar Kedungmulyo Jombang. Skripsi : Semarang

Noor, S.R. (2002). Peran Perempuan dalam Keluarga Islami. 2002. Diakses 14 Seprember 2018, dari sofiapsy.staff.ugm.ac.id

Pahl, KM, Barret, PM. 2010. Preventing Anxiety and Promoting Social and Emotional Strenht in Preschool Children: A Universal Evaluation of The Fun FRIENDS. Advacesin School Mental Health Promotion. Volume 3 ISSUE 3. The Clifford Beers Foundation \& University Of Maryland

Shonkoff JP. (2012). Technical report: The lifelong effects of early childhood adversity and toxic stress. Pediatrics Journal, 129:232-46

WHO. 2015. Sustainable Development Goal's. In: Station U, editor. Jakarta : United Nation 